\title{
Capripoxviruses of small ruminants: control and evaluating the future update efficacy of a current vaccine in Egypt
}

\author{
Eman B. Abd-Elfatah ${ }^{1}$, Mamdouh F. El-Mekkawi ${ }^{1}$ and Emad A. Aboul-Soud ${ }^{2}$ \\ ${ }^{1}$ Department of Animal Medicine, Division of Infectious Diseases, Faculty of Veterinary Medicine, Zagazig University, Sharkia, Egypt \\ ${ }^{2}$ Veterinary Serum and Vaccines Research Institute, Department of Pox, Abbasia, Cairo, Egypt
}

Correspondence Author: Eman B. Abd-Elfatah, Department of Animal Medicine, Division of Infectious Diseases, Faculty of Veterinary Medicine, Zagazig University, Sharkia, Egypt

Received date: 12 August 2018, Accepted date: 10 December 2018, Online date: 25 December 2018

Copyright: (C) 2018 Eman B. Abd-Elfatah et al., This is an open-access article distributed under the terms of the Creative Commons Attribution License, which permits unrestricted use, distribution, and reproduction in any medium, provided the original author and source are credited.

\begin{abstract}
Sheeppox (SPP) and goatpox (GTP) diseases of sheep and goats known as Capripoxviral (CaPVs) diseases closely related to lumpy skin disease (LSD) of cattle, have an important role in agricultural economy. CaPVs diseases are not completely host specific, many of them show a clear host preference with more virulent in one of a two species. In Egypt where CaPVs diseases are enzootic, vaccination and bio-security are the only two control measures that targeted by an effective vaccination and limitation of animal movement and their products between different countries, in Egypt, CaPVs diseases controlled with a live attenuated tissue-culture SPP vaccine (Romanian strain) (RSPP vaccine) has been produced at Veterinary Serum and Vaccine Research Institute (VSVRI) because of the antigenic relationship in between. The current situation and the reoccurrence of the CaPVs diseases especially LSD in Egypt and inability of commercial RSPP vaccine to provide vaccinated animals with full protection so a trail of preparation and evaluation the trivalent vaccine (Romanian, Kenyan) SPP vaccine and GTP vaccine with equal volume and titre firstly in its specific and preferable host is a good idea to increase the immunization of a commercial Romanian SPP vaccine, thus it can be used to protect all CaPVs diseases. Conclusion: In Egypt where the CaPVs diseases are endemic, an efficient vaccine considered the main control measures to reduce the reoccurrence of the diseases, further preparation and field evaluation of safe and efficient trivalent CaPVs vaccine regarding on previous references was provided vaccinated animals with effective immunity than commercial RSPPV vaccine, beside the appropriate bio-security measures.
\end{abstract}

Key words: CaPVs, Control, Egypt, GTP, Immunity, SPP

\section{INTRODUCTION}

Sheeppox (SPP) and Goatpox (GTP) viral diseases are one of an important contagious infectious disease affecting small ruminants in Africa, one of a main diseases requiring immediate solution as it listed in Group A diseases by the World Organization for Animal Health (OIE), one of the notifiable diseases. The causative agents sheeppox virus (SPPV) and goatpox virus (GTPV) are a member of the Poxviridae family, Chordopoxvirinae subfamily and Capripoxvirus (CaPVs) genus along with Lumpy skin disease virus (LSDV) of cattle, the other member of the genus [1], share a major neutralization site with cross protection and antigenic relationship [2]. SPP disease is endemic in the Middle East including (Egypt, Iran, Afghanistan), North Africa, Turkey, Iraq and India as well as South-Eastern Europe where a sporadic outbreak were occurred [3]. In countries infected with SPP and GTP diseases economically affected with reducing the productive potential of the existing sheep and goat industries, a little information on the economic losses of SPP disease in dairy flocks, it causes considerable economic loss due to reduced meat and milk production, abortion, depreciation of wool and skin quality [4], tanning sector due to its slow progress of viral and permanent scar formation [5,6], this Economic investigations affected with some variables such as number of an infected animals compared with flock size, number of days of illness [7,8]. Morbidity and mortality rate vary with a breed of the animal, its immunity to CaPVs and a strain of the viruses. CaPVs diseases affecting all age groups of animals, mortality rate varies between 5-10\%, the ratio can reach to 50\% in young animals, SPP and GTP diseases is highly destructive and cause limitation of international trade [9]. The clinical signs are severe in lambs, stressed animals, animals that have concurrent infections or that come from areas where pox is not endemic particularly European races are more susceptible to disease and can show high mortality as $100 \%$ while the native flocks have natural immunity against viruses with mild clinical signs of the disease $[10,11,12]$.

The objective of this article is to give insight on the efficacy control measures through an effective vaccine and evaluating the CaPVs vaccine by using the cellular and the humoral assays with a role of a maternal immunity in a protection of a new-born animals.

\section{DIFFERENTIAL AND ANTIGENIC RELATIONSHIP}

In previous, SPPV and GTPV were believed to be same virus. However, genetic sequencing proved that these are a separate viruses, SPPV and GTPV considered to be host specific but some strains found to infect both sheep and goats as isolates from Kenya, Yemen and Oman naturally infect both goats and sheep while most SPPV and GTPV isolates show distinct host preferences with more virulent in one of the two species (goats may become mildly infected with 
SPPV which could cause severe disease when transmitted back to sheep, similarly sheep can be infected with virulent GTPV [13]. In India SPPV signature residue of P32 gene found in an infecting goat and GTPV associated with disease in sheep detected by P32 and RP030 gene based species-specific PCR methods [14]. Clinical finding of both SPP and GTP diseases were similar and inability to differentiate by serology assays lead to suggest that these diseases a part of disease complex caused by single viral species as there is a high degree of genome homology between different CaPvs isolates with $96 \%$ or greater shared genetic sequence [2]. Cross protection between SPPV and GTPV is partial, so a complete protection with a homologous vaccine was recommended [10,15]. Therefore, in the most countries at least two different vaccines containing the isolates of either GTPV or SPPV are necessary to protect small ruminants against both viruses $[16,17,18]$. Differentiation between SPPV and GTPV can be possible at molecular level targeting host range genes $[19,20]$ using whole genome sequencing and P32 gene using polymerase chain reaction-restriction fragment length polymorphism (PCR-RFLP) used specific primers on a multiplex basis [21,22]. ORF 095 and ORF 103 genes could be used for the genotyping of the SPPV, sequence analysis of the two genes may be recognized as new markers to distinguish GTPV and SPPV [23]. RPO30 gene-based PCR depend on primers used bind [24,22,25].

\section{CONTROL AND ERADICATION STRATEGY}

CaPVs diseases in its regular course begin to show clinical signs after a 1-2 week of an incubation period, CaPVs diseases do not have a specific treatment depending on a supportive treatment. The disease spreading can be prevented by isolating of the infected animals and herds, commercial restrictions, taking quarantine measures and disinfection [16]. Control of the disease depend mainly on an obligatory laboratory diagnosis for termination of quarantine application as this disease notified in an infected country. In CaPVs free countries maintain their status by controlling the importation of infected animals and their products from enzootic areas, once the disease has entered, a slaughter of infected and in-contact animals, vaccination of neighboring flocks with a dead vaccine, strict animal movement control, sentinel animals could be used prior to re-stocking culled herds [26] as in European Union (EU) member states where restriction to use of SPP live vaccine. It has been reported that some live attenuated vaccines induced severe reactions at the injection site or even mild disease in vaccinated animals $[11,27]$.

In most countries where CaPVs are enzootic due to prolonged stability of the virus on wool and dried scales of the recovered animals and unregulated introduction of livestock through importation or by illegal means of an infected ruminants and a slaughter policy would be impracticable and movement controls impossible to enforce perfectly in these countries, all these factors hinder the control of the disease. On other hand easy detection of infectious agents, economic importance of the diseases, absence of reservoir host, induction of a long time of immunity after vaccination, low annual turnover rate of animals in flocks and easy diagnosis of infected or exposed animals all this factors favor the initiate of control programs but vaccination is considered the most eas y and effective protection way against all CaPVs diseases $[26,28,29]$. It is essential to vaccinate small ruminants' flocks regular with a safe and efficient vaccine for the control of this serious and economical importance of the diseases in endemic area [4].

In hyper-endemic areas, ring vaccination should be undertaken for about 3 years to try an eradication of the diseases [15]. First vaccination against SPP and GTP diseases was made as ovulation which was applied by infected scab material into the scratch formed on the bottom or subcutaneous inoculation of the suspension prepared in glycerinated saline, this application has been used in the Indian and Mid-Asian countries for centuries until commercial vaccination was possible [30], live attenuated SPP and GTP vaccines already used for protection against CaPVs infection are thermostable in lyophilized form, only a single immunization required with immunity may lasts for long period, when annual vaccination was recommended provide good protection and able to control the outbreaks of the diseases [31] for example 0240 Kenya sheep and GTP vaccine strains used in sheep and goats, Romanian and RM-65 vaccine strain used mainly in sheep, and Mysore and Gorgan vaccine strains used in goats for long life immunity [32] while immunity of inactivated vaccine shorter (up to six months), more common in non-endemic countries as an emergency vaccine and safer option with ring vaccinations in combination with culling, quarantine and movement restrictions [33]. Susceptible animals can be vaccinated through intradermal or subcutaneous route with OIE recommended safe dose (10 ${ }^{2.5}$ TCID50)[32].

\section{MECHANISM OF IMMUNITY}

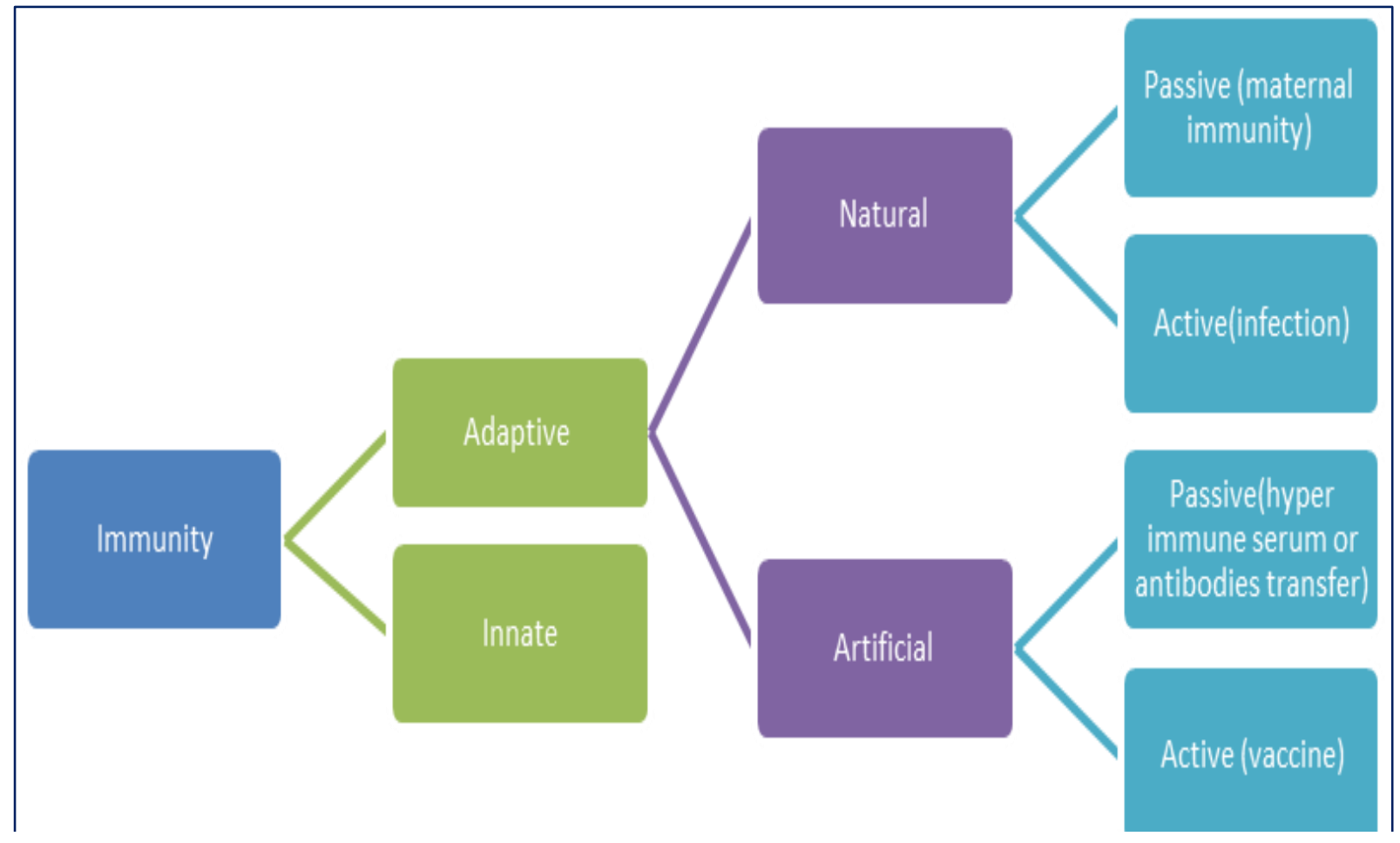

Fig 1: Calssification of immunity

Immunity against CaPVs infection and vaccine depend on both the cell mediated immunity (CMI) and the humoral immunity. CMI response considered the predominant route in eliminating the infection against $\mathrm{CaPVs}$, in addition to a protective antibodies (Abs) that limit spread of the infection within the body for 
a long period in the immunized animals [34,35], SPPV-neutralizing Abs considered an available guide point for evaluating the humoral immunity[36]. Adaptive immunity is essential for inhibition of viral infections and keep a memory to prevent the repeated infections caused by the same pathogen a few days to weeks after activation of immunity [37]. Following vaccination, some virus particles are phagocytosed by a macrophages and their proteins cleaved into short peptides that presented on the surface of the macrophage associated with MHC (Major Histocompatibility Complex) class $\Pi$ protein, this combination recognized by appropriate clones of CD4 T lymphocyte cells [38]. Differentiation of the activated CD4 + T cells results into Thelper Th1, Th2 cells, Th1 cells secrete interferongamma (IFNy), interleukin IL-2 and lymphotoxin that stimulate inflammatory immune responses as delayed-type hypersensitivity, production of complementfixing Abs and cytotoxic T lymphocytes that responsible for cellular immunity. Th2 cells secrete IL-4, IL-5 and IL-10, which regulate the humoral immune response [39,40]. On the other hand, virus infected cells express antigens associated with MHC class I on its surface and activate CD8+ T cells MHC I carrying the antigenic determinant binds to the TCR (T cell receptor) through CD80 and CD86, it provides signals to CD8+ T lymphocyte cells [41,40] after receiving the signals from the infected cells, CD8+ T cells are started proliferation and differentiation into CT Lyses, it can lyses the infected cells by secreting perforin and granzymes and activates cytokines like TNF- $\alpha$, IL-2 and IFN $\gamma$ to promote apoptosis by the macrophages $[42,40]$.

\section{SOME ASSAYS TO EVALUATE CELLULAR IMMUNITY}

Cellular immunity is the most characteristic feature of poxvirus immunity [35]. The immunological studies in the recent years have focused on the role of CMI in defense against animal infections, this has accentuated the importance of examining CMI as part of any thorough effort to characterize the response of immunity to infection or administration of vaccination [43]. Level of lymphocytes proliferation placed in short- term tissue culture in the response to an antigen correlates with the expansion of antigen-specific lymphocytes in response to vaccination or infection, this indicates the superior responses of the memory cells in the animal immunity, this applied on peripheral blood mononuclear cells (PBMCs) from an individual animal [44,45]. Tetrazolium salt reagents as XTT and MTT has become the gold standard for determine the cell viability and proliferation since it developed by [44], MTT or XTT reagent depend on color changes under the metabolic conditions of proliferating lymphocytes [46]. Cytokines are produced locally and at a low level so a difficulty to detect it systematically, the functional analysis of the effector cells generated upon activation of leukocytes that regulate a physiological and pathological functions including innate immunity, in vitro stimulation of cultured PBMCs with virus can be helpful to investigate virus induced cytokine production [47]. Using of ELISA method to measure the quantification of cytokines are costly and analyzed a limited numbers of cytokines in a single sample, so a reverse transcriptase quantitative polymerase chain reaction (RT-qPCR) is a routine method used to investigate cytokines transcripts gene expression using a small quantities of sample with high specificity, sensitivity and accuracy, a control gene that is not affected by the experimental treatment must be used to correct for variations due to differences in RNA quantity [48,49]. IFN- $\gamma$ cytokines plays central role in regulation of immune body response against intracellular pathogens [50]. IFN $\gamma$ assay system is a rapid, sensitive to measure antigen specific cell mediated reactivity when compared with the lymphocyte proliferation assay, that's one of the first in-vitro cellular assay used as a routine diagnostic test in veterinary medicine [51]. Expression of inflammatory cytokines (IFN- $\gamma$ ) in PBMCs by Rt-PCR observed in the early days after vaccination and at the onset of clinical finding of CaPVs infection [52].

\section{SOME ASSAYS TO EVALUATE THE HUMORAL IMMUNITY}

Production of Abs is the main function of the humoral immune system, Abs are secreted by the plasma cells and occur in two physical forms, a soluble form that is secreted from the cell to be free in the blood sera and tissue fluid to invade microorganisms and a membrane-bound form that is attached to the surface of a B cell and is referred as the B-cell receptor (BCR) that found on a surface of B cells and facilitates the activation of these cells and subsequent differentiation of cells into either antibody factories called memory B cells that are survive in the body and remember same antigen [53]. Abs were observed after $1^{\text {st }}$ week of live or in activated SPP vaccine administration, the highest titre obtained after $3^{\text {rd }}$ or $4^{\text {th }}$ week then was gradually decline, vaccinated animals or those showing mild signs of SPP disease were developed only low level of neutralizing Abs which are often below the detection limits of currently available serological tests [26]. Serological assays are not capable of differ between neutralizing Abs from vaccination or infection, the agar gel immunodiffusion and indirect immunofluorescent antibody tests are not sensitive in Abs detection at low level due to cross reactivity with other poxvirus Abs as the Parapoxvirus [54]. Serum neutralization test (SNT) is the most specific serological test and a gold standard for estimation of Abs against all CaPVs, not sensitive enough to enable reliable detection of low levels of Abs present in some animals following recovery from natural infection [55]. ELISA is easier to perform, does not require live CaPVs and sensitive to detect CaPVs Abs at early infection or vaccination $[56,57]$.

\section{MATERNAL IMMUNITY}

Pregnant small ruminants vaccinated with different vaccines among them SPP and GTP vaccine was effective in producing hyperimmune colostrums for new-born lambs and kids during their first seven days [58]. Immunoglobulin $\mathrm{G}(\mathrm{IgG})$ is the main Ig in the blood system may be transferred to offspring through either the colostrums or the placenta and responsible for neutralizing viruses [59]. Different breeds of small ruminants show varying degrees of natural resistance against infection with SPPV and GTPV, maternal immunity provides protection against SPP and GTP diseases up to 3 months [60]. Vaccination of pregnant goats at 4 months of pregnancy by GTPV provided their kids with high titre of Abs in colostrums compared with pregnant goats vaccinated at 2 month of pregnancy [61].

\section{CAPRIPOXVIRUSES VACCINE IN EGYPT}

In Egypt where CaPVs diseases are endemic, vaccination and bio-security measures are the most efficient and cost effective method to control the diseases [62], a live attenuated tissue culture SPPV vaccine proved to be sterile, safe, potent enough to be used in the field and economic as every lyophilized vial ( $1 \mathrm{ml}$ virus fluid diluted with $1: 100$ saline) used for vaccination of approximately 100 lambs $(1 \mathrm{ml} / \mathrm{lamb})$ [63]. In Egypt, live attenuated freeze-dried vaccine (RSPPV) used to control SPP disease in sheep and LSD in cattle. Furthermore, SPPV and GTPV do not occur in Southern Africa only attenuated LSD vaccine are used against LSDV, whereas in northern, central Africa and in the Middle East, where the distribution of SPP, GTP and LSD viruses are endemic, an attenuated SPPV vaccines, such as KSGP O-240, RM65 and RSPPV strains have been used against LSD $[26,64,65]$. In the recent years, the appearance of non-published and published outbreak of SPPV in different regions of Egypt as in Alhendaw, Eldakhla, Al Wadi Al Jadid; Kafr Ash Shaykh; Al Minya; Asyut with morbidity rate $33.33 \%, 5.3 \%, 40 \%, 12.5 \%$ respectively [66], Menya Al Qamh, Sharkia with morbidity rate $23.5 \%$ and $8.2 \%$ mortality rate of young infected lambs [67], in addition to there has been a significant prevalence of un published LSD and the lack of SPPV immunization alone to counteract this spread, the incomplete protection against LSD has been reported in cattle vaccinated with RSPPV vaccine and appearance of an infectious cases of LSDV in the previously vaccinated animals [68,69]. All CaPVs strains were antigenically related, GTPV and LSDV are closely related than to SPPV [19], Kenyan SPP vaccine used for immunization in both small ruminant and cattle [31,70]. During 2006 outbreak of LSD in Egypt, it was reported that the live attenuated SPP vaccine did not provide cattle with complete protection against LSDV [71]. GTP vaccine are not commercially available in any Arabian or African countries, shepherds occasionally rely on heterologous SPP vaccine to goats in spite of the fact that goats highly exists in Egypt and in these countries and goats with SPP vaccines or sheep with GTP vaccines are fully unsuccessful [72]. In Egypt the three CaPVs (SPPV,GTPV,LSDV) were endemic and appeared in a sporadic and in an outbreak cases so from all these previous factors have been thought of trying to use a candidate trivalent vaccine of SPPV strains (Romanian, Kenyan) and GTP strain with equal volume and titres in its specific and preferable host because SPPV and GTPV do not replicate in small rodents, there are no small animal models available to evaluate its efficacy, this candidate vaccine evaluated by the cellular and the humoral immunity and gave better immunity for all CaPVs comparative with commercial monovalent RSPPV vaccine $[73,74,75]$. 


\section{CONCLUSION AND RECOMMENDATION}

SPPV, GTPV and LSDV are an important viral disease that significantly impact the livestock industry with a high degree of sequence homology and a cross protective immunity. In Egypt where the distribution of all CaPVs diseases are endemic there isn't any specific treatment, quarantine measures are difficult to implement it perfectly due to trade of an infected animals and their products as wool and hides, the viruses can be stable for a long period, in addition to the movement of an insect vector, it is essential to conduct studies to estimate the actual prevalence and to explore potential risk factors that can contribute to the spread and maintenance of these viruses among animals. Especially in endemic area with SPPV, GTPV and LSDV diseases, an attenuated SPPV vaccines as RM65, KSGP O-240 and Romanian SPPV strains have been used against LSDV, however in the last years the reoccurrence of the diseases, SPPV vaccine (Romanian strain) failed to stop recurrent appearance of the diseases especially LSD, so the preparation of combined trivalent vaccine (Romanian, Kenyan, GTP) used as broad-spectrum vaccine candidate against all CaPVs diseases is a good trail with a remarkable high immunity compared with commercial SPPV vaccine alone. Vaccine efficacy based on the total protective effect to a vaccinated animals that depend on a clinical outcome, CMI involves the activation of phagocytes, antigen-specific cytotoxic T- lymphocytes and the release of various cytokines in response to an antigen especially in the first period after vaccination or infection. Seroconversion studies are commonly performed when evaluating veterinary vaccines through production of the defense Abs. The evaluation of a vaccine experimentally after administration is a necessary step to knowledge the efficacy of the vaccine, further studies of an evaluation of the vaccine in its preferable and specific host is the first step for detect the efficacy of the vaccine experimentally and in field application, in addition to a maternal immunity.

Nothing to disclose

\section{ACKNOWLEDGMENTS}

\section{REFERENCES}

[1] King, A.M.Q., M.J. Adams, E.B. Carstens and E.J. Lefkowitz,2011. Virus taxonomy: Classification and nomenclature of viruses. Elsevier London UK, 291309.

[2] Tulman, E.R., C.L. Afonso, Z. Lu, L. Zsak, J.H. Sur, N.T. Sandybaev, U.Z. Kerembekova, V.L. Zaitsev, G.F. Kutish and D.L. Rock,2002. The genomes of sheeppox and goatpox viruses. Journal of Virology, 76 (12):6054-6061.

[3] OIEa,2017. International des Epizooties (World Health Organization for Animals) Manual of Diagnostic Tests and Vaccines for Terrestrial Animals. Sheeppox and Goatpox, 7 (13): 1-12.

[4] Yeruham, I., H. Yadin and M. Van Ham, 2007. Economic and epidemiological aspects of an outbreak of sheeppox in a dairy sheep flock. The Veterinary Record,160 (7): 236-237.

[5] Ozmen, O., M. Kale, M. Haligur and S. Yavru, 2009. Pathological, serological and virological findings in sheep infected simultaneously with Bluetongue, Peste-des-petits-ruminants, and Sheeppox viruses. Tropical Animal Health Production, 41: 951-958.

[6] Gitao CG., C. Mbindyo, R. Omani and V. Chemweno, 2017. Review of Sheep Pox Disease in Sheep. Journal of Veterinary Medicine and Research, 4(1): 1068.

[7] Garner, M.G., S.D. Sawarkar and E.K. Brett, 2000. The Extent and Impact of Sheeppox and Goatpox in the State of Maharashtra, India. Tropical Animal Health and Production, 32: 205-223.

[8] Senthilkumar, V., M. Thirunavukkarasu,2010. Economic losses due to sheeppox in sheep farms in Tamil Nadu. Journal of Veterinary and Animal Sciences, 5(6): 88-94.

[9] Hurisa TT., Z. Jing, H. Jia, G. Chen and X.B. He, 2018. A Review on Sheeppox and Goatpox: Insight of Epidemiology, Diagnosis, Treatment and Control Measures in Ethiopia. Journal of Infectious Diseases and Epidemiology, 4(3):2474-3658.

[10] Rao, T.V.S. and S.K. Bandyopadhyay,2000. A comprehensive review of Goatpox and Sheeppox and their diagnosis. Animal Health Research Reviews, 1(2): $127-132$.

[11] Mangana, O., C. Kottaridi and K. Nomikou, 2008. The epidemiology of sheeppox in Greece from 1987 to 2007. Revue scientifique et technique (International Office of Epizootics), 27(3): 899-905.

[12] Beard, P.M., S. Sugar and A .Bazarragchaa, 2010. Description of two out breaks of Capripoxviruse disease in Mongolia. Veterinary Microbiology, 142(3-4): 427- 431.

[13] Kitching, R.P. and W.P. Taylor, 1985. Clinical and antigenic relationship between isolates of sheep and goatpox viruses. Tropical Animal Health Production, 17(2): 64-74.

[14] Bhanuprakash, V., G. Venkatesan, V. Balamurugan, M. Hosamani, 2010. Pox outbreaks in sheep and goats at Makhdoom (Uttar Pradesh), India: evidence of sheeppox virus infection in goats. Transboundary and Emerging Diseases,57(5): 375-382.

[15] Bhanuprakash, V., A.R.S. Moorthy, G. Krishnappa, R.N. Srinivasa Gowda, B.K. Indrani, 2005. An epidemiological study of sheeppox infection in Karnataka state, India. Revue scientifique et technique (International Office of Epizootics), 24 (3): 909-920.

[16] Abu-Elzein, E., F. Housawi and O. Ramadan, 2003. Observations on natural and experimental infection of sheep and goats with a virulent field Capripoxvirus with high affinity to goat. VeterinarskiArhiv, 73 (3): 119-131.

[17] Radostits, O.M., C.C. Gay and K.W. Hinchcliff, 2006. Veterinary Medicine. 10th Edn. Saunders, pp 1430-1431.

[18] Iran Veterinary Organization, 2013. survey analysis on sheep pox and goat pox in IRAN during 2010-2014. Pox National CommiteeBultin of Iran Veterinary Organization, Tehran, Iran.

[19] Le Goff, C., C.E. Lamien, E .Fakhfakh, A. Chadeyras and E. Aba-Adulugba, 2009.Capripoxvirus G- protein- coupled chemokine receptor :A host range gene suitable for virus animal origin discrimination. Journal of General Virology, 90 (8):1967-1977.

[20] Santhamani, R., R. Yogisharadhya, G .Venkatesan, S.B. Shivachandra, A.B. Pandey and M.A. Ramakrishnan,2013. Detection and differentiation of sheeppox virus and goatpox virus from clinical samples using $30 \mathrm{kDa}$ RNA polymerase subunit (RPO30) gene based PCR. Veterinary World, $2231-0916$.

[21] Hosamani, M., B. Mondal, P.A. Tembhurne, S.K. Bandyo- Padhyay and R.K. Singh, T.J. Rasool, 2004. Differentiation of sheeppox and goatpox viruses by sequence analysis and PCR-RFLP of P32 gene. Virus Genes, 29(1):73-34

[22] Tuppurainen, E.S., E.H .Venter and J.A. Coetzer, 2005. The detection of lumpy skin disease virus in samples of experimentally infected cattle using different diagnostic techniques. OnderstepoortJournal of Veterinary Research, 72 (7): 153-164.

[23] Zhu, X.L., F. Yang, H.X. Li and Y.X. Dou,2013. Identification and phylogenetic analysis of a Sheeppoxvirus isolated from the Ningxia Hui Autonomous Region of China. Genetics and Molecular Research, 12 (2):1670-1678.

[24] Lamien, C.E., M. Lelenta, W. Goger, R. Silber, E .Tuppurainen, M. Matijevic, A.G. Luckins and A. Diallo, 2011 . Real time PCR method for simultaneous detection, quantitation and differentiation of capripoxviruses. Journal of Virological Methods, 171: 134-140.

[25] Mahmoud, M.A. and M.H. Khafagi, 2016. Detection, identification, and differentiation of sheeppox virus and goatpox virus from clinical cases in Giza Governorate Egypt, Veterinary World, 9(12):1445-1449.

[26] Kitching, R.P.,1986a. The control of sheep and goatpox. Revue Scientifique et Technique de l'OIE (France), 5:503-511.

[27] Boumart, Z., S. Daouam, I .Belkourati, L. Rafi, E .Tuppurainen, K. O. Tadlaoui and M.E. Harrak, 2016. Comparative innocuity and efficacy of live and inactivated sheeppox vaccines. BMC Veterinary Research, 12:133-139.

[28] Rweyemamu, M.M., P.L. Roeder and W.P. Taylor, 2006. Towards the global eradication. In: Barret T, Edn.). Cambridge: Institute of Animal Health, Biology of Animal Infection Series, Academic Press, pp 99-322.

[29] Bhanuprakash, V., 2011. Prospects of control and eradication of capripox from the Indian subcontinent: A perspective. Antiviral Research, 91 (3): 225-232. 
[30] Sozdutmaz, İ.,2010. Virological, serological and epizootiological investigations of sheeppox and goatpox diseases in northeast Anatolian region (Doctoral dissertation), No. 260529.

[31] Kitching, R.P., 2003. Vaccines for lumpy skin disease, sheeppox and goatpox. Developments in biological, 114: 161-167.

[32] OIE (Office International des Epizooties)., 2014. Sheeppox and goatpox Manual of Diagnostic Tests and Vaccines for Terrestrial Animals, Paris. Chapter 2. 7(14):1-12.

[33] Awad, M., A. Michael, S.M. Soliman, S.S. Samir and A.M. Daoud,2003. Trials for preparation of inactivated sheeppox vaccine using binary ethyleneimine. Egyptian Journal of Immunology, 10: 67-72.

[34] Panchanthan, V., G. Chaudhri and G. Karupiah, 2008. Correlates of protective immunity of poxvirus infection: where dose antibody stand. Immunology and cell biology, 86(1):80-68.

[35] Green, S., F.A. Ennis and A. Mathew,2011. Long term recall of memory CD8T cells in mice to first and third generation smallpox vaccines. Vaccine., 29(8):1666-1676.

[36] Rashwan, S. M., H.N. A1 Khalaf, M. I. Al Hammad, M. H. Abdel-Baky and A.H. Azab,2011. Determination of sheeppox circulating neutralizing antibodies in immunized sheep and goats in the North Region of the Kingdom of Saudi Arabia. Journal of Applied Animal Research, 19: 233-235.

[37] Libbey, J.E. and R.S. Fujinami, 2014. Adaptive immune response to viral infections in the central nervous system. Handbook of Clinical Neurology, 123: 225-247.

[38] Bloom, B.R. and R. Zinkernagel,1996. Immunity to infection -overview. current opinion immunology journal, 8:465- 466.

[39] Boeuf, P., I. Vigan-Womas, D. Jublot, S. Loizon, J.C. Barale, B.D. Akanmori, O. Mercereau-Puijalon and C .Behr, 2005. CyProQuant-PCR: a real time RTPCR technique for profiling human cytokines, based on external RNA standards, readily automatable for clinical use. BMC Immunology. $2005 ; 6: 5$.

[40] Thakur, A., E.P. Lasse and J. Gregers, 2012. Immune markers and correlates of protection for vaccine induced immune responses. Vaccine, 30(33):49074920.

[41] Andrews, N.P, C.D. Pack and A.E. Lukacher, 2008. Generation of Antiviral Major Histocompatibility Complex Class I-Restricted T Cells in the Absence of CD8 Co receptors. Journal of Virology, 82(10):4697-4705.

[42] Ruby, J., H. Bluethmann and J.J. Peschon, 1997. Antiviral Activity of Tumor Necrosis Factor (TNF) Is Mediated via p55 and p75 TNF Receptors. The Journal of Experimental Medicine, 186(9): 1591-1596.

[43] Sandbulte, M. R. and J.A. Roth, 2004. Methods for analysis of cell-mediated immunity in domestic animal species. Journal of the American Veterinary Medicine Association, 225.522.

[44] Mosmann, T.,1983. Rapid colorimetric assay for cellular growth and survival: application to proliferation and cytotoxicity assays. Journal of immunological methods, 65:55-63.

[45] Roehm, N.W., G.H. Rodgers and S.M. Hatfield, 1991. An improved colorimetric assay for cell proliferation and viability utilizing the tetrazolium salt XTT. Journal of immunological methods, 142:257-265.

[46] Stockert, J.C., A. Blázquez-Casto, M. Cañete, R.W. Horobin and A. Villanueva,2012. MTT assay for cell viability: intracellular localisation of the formazan product is in lipid droplets. Acta Histochemica,114:785-96.

[47] Khan, M.M., 2008. Role of cytokines. In: Khan MM, editor. Immunopharmacology. Amsterdam: Elsevier, pp 33-59.

[48] Faver, N., G. Bordmann and W. Rudin, 1997. Comparison of cytokine measurements using ELISA, ELISPOT, and semi quantitative RTPCR. Journal of Immunological Methods, 204(1): 57-66.

[49] Giulietti, A., L. Overbergh, D. Valckx, B. Decallonne, R. Bouillon and C. Mathieu, 2001. An overview of real-time quantitative PCR: applications to quantify cytokine gene expression. Elsevier Journal, 25:386-401.

[50] Shtrichman, R. and C.E. Samuel, 2001. The role of gamma interferone in antimicrobial immunity. Current opinion in microbiology, 4 (3): 251-259.

[51] Rothel, J.S., S.L. Jones, L.A. Corner, J.C. Cox and P.R. Wood, 1992. The gamma-interferon assay for diagnosis of bovine tuberculosis in cattle: conditions affecting the production of gamma-interferon in whole blood culture. Australian veterinary journal, 69(1):1-4.

[52] Norian, R., N. Afzal Ahangran, H.R. Varshovi and A. Azadmehr, 2017. Evaluation of Cell-mediated Immune Response in PBMCs of Calves Vaccinated by Capripox Vaccines using ELISA and Real-time RT-PCR. Research in Molecular Medicine, 5 (2): 3-8.

[53] Borghesi, L. and C.Milcarek, 2006. From B cell to plasma cell: regulation of V(D)J recombination and antibody secretion. Immunologic Research, 36 (1-3): $27-32$.

[54] Kitching, R.P., J.M. Hammond and D.N. Black, 1986. Studies on the major precipitating antigen of Capripoxvirus. Journal of general virology, 67: 139-148.

[55] Chand, P., R.P. Kitching and D.N. Black, 1994. Western blot analysis of virus-specific antibody responses to Capripoxvirus and contagious pustular dermatitis infections in sheep. Epidemiology and infection,113 (2): 377-385.

[56] Babiuk, S., D.B. Wallace, S.J. Smith, T.R. Bowden, B. Dalman, G .Parkyn, J. Copps and D.B. Boyle,2008. Detection of Antibodies Against Capripoxviruses using an Inactivated Sheep pox Virus ELISA .Transboundary and Emerging Diseases, $56: 132-141$.

[57] Tian, H., Y. Chen, J. Wu, Y .Shang and X .Liu, 2010. Serodiagnosis of sheep pox and goat pox using an indirect ELISA based on synthetic peptide targeting for the major antigen P32. Virology Journal, 7:245.

[58] Burezq, H,A. and M. A. Razzaque, 2018.Effects of immunizing pregnant ewes and does on the humoral immune response of secreted colostrums. The Journal of Animal and Plant Sciences, 28 (1): 341-347.

[59] Atkinson, D.E., R.D.H. Boyd and C.P. Sibley, 2000. Placental Transfer. Elsevier, Manchester, pp. 2787-2846.

[60] Kitching, P., 1986b. Passive protection of sheep against Capripoxvirus. Research in veterinary science, 41: 247-250.

[61] Mervat, M. Ali., A.E. S. Amera, A. F. Amal, M. S. Soad and A.M. Daoud, 2005. Monitoring the maternal immune response in kids from goatpox vaccinated dams. Egypt Veterinary Medicine Association, 65 (6):37-44.

[62] Elbayoumy, M.K., W.M. Ghattas, A.M. Allam and M.A. Mahmoud, 2013. Immunological Studies for Using of Combined Inactivated Respiratory Virus Vaccine (Pneumo-3) and Sheeppox Vaccine in Goats. Academic Journal of Animal Diseases, 2(1): 01-06.

[63] Rizkallah, S.S., 1994. Further studies on sheeppox disease in Egypt. PhD. Thesis, (infectious and fish disease).Faculty of Veterinary Medicine, Cairo University.

[64] Brenner, J., M. Bellaiche, E. Gross, D. Elad, Z .Oved, M. Haimovitz, A. Wasserman, O .Friedgut, Y .Stram, V .Bumbarov and H .Yadin, 2009. Appearance of skin lesions in cattle populations vaccinated against lumpy skin disease: statutory challenge. Vaccine journal, 27: 1500-1503.

[65] Somasundaram, M.K.,2011. An outbreak of lumpy skin disease in a holstein dairy herd in Oman: a clinical report. Asian Journal of Animal and Veterinary Advances, 6(8):851-859.

[66] OIEb.,2017. Sheeppox and goatpox, Egypt. General Organization for Veterinary Services (GOVS), Ministry of Agriculture and Land Reclamation, Cairo, Egypt.

[67] Eman, B Abd-Elfatah., M.F. El-Mekkawi, M. B. Iman and M.F. Elshaima, 2018. Identification and phylogentic analysis of sheeppox during an outbreak of sheep in Sharkia Governorate, Egypt. Genetics and Molecular Research, 17 (2): 16039901.

[68] Elhaig, M.M., A. Selim and M. Mahmoud, 2017. Lumpy skin disease in cattle: Frequency of occurrence in a dairy farm and a preliminary assessment of its possible impact on Egyptian buffaloes .Onderstepoort Journal of Veterinary Research, 2219-0635.

[69] Fatma, M. Abdallah., M. E. Hend and FK.Gamilat, 2018. Sporadic cases of lumpy skin disease among cattle in Sharkia province, Egypt: Genetic characterization of lumpy skin disease virus isolates and pathological findings. Veterinary World, 2231-0916.

[70] Gelaye, E., A. Belay, G .Ayelet, S. Jenberie, M. Yami, A. Loitsch, E. Tuppurainen, R. Grabher, A .Diallo and C.E Lamien, 2015 . Capripox disease in Ethiopia: Genetic differences between field isolates and vaccine strain, and implications for vaccination failure.Antiviral Research, 119: 28-35.

[71] Salib, F.A. and A.H. Osman, 2011. Incidence of lumpy skin disease among Egyptian cattle in Giza Governorate, Egypt. Veterinary World, 4: $162-167$.

[72] Agrawal, S.K. and J.P. Soman, 1997. Assessment of immune efficacy of attenuated live goatpox vaccine against sheeppox and contagious ecthyma. Indian Veterinary Journal, 74(12): 1016-1018. 
Citation: Eman B. Abd-Elfatahet al.,2018. 2018. Capripoxviruses of small ruminants: control and evaluating the future update efficacy of a current vaccine in Egypt. Advances in Environmental Biology.12(12): 11-16.DOI:10.22587/aeb.2018.12.12.3

[73] Christine, A. Mikhael., J.P. El-Sanousi, I. M. Reda and M. S Soad, Preparation of univalent and bivalent Capripox vaccines. 5th Science conference of Egypt For Animal Management, 55-69.

[74] Christine, A. Mikhael., E. N. Olfat and A. M. Namaa, 2017. Study on the capability of a dual capripox vaccine in protection of cattle against LSD infection. Journal of veterinary medicine research, 24 (1): 224-233.

[75] Aboul-Soud, E.A., M.H. Kafafy, S.A. El-Suall, M.A. Zaghloul and A. M. Christine, 2018.preparation of trivalent vaccine against lumpy skin disease using different Capripox viral strain (in press) 